\title{
ПРАВО
}

УДК 347.9

DOI: $10.21779 / 2500-1930-2020-35-4-104-108$

\section{Н.Ш. Гаджиалиева}

\section{Расширение правил подсудности в гражданском процессе}

Дагестанский государственный университет; Россия, 367000, г. Махачкала, ул. М. Гаджиева, 43a; naidka79@mail.ru

Проведен анализ последствий устранения термина «подведомственность» из процессуального законодательства в результате принятия Федерального закона от 28 ноября 2018 г. № 451-Ф3. В частности, анализируются не только новое содержание института подсудности, но и обновленные правила передачи дела по подсудности между судами общей юрисдикции и арбитражными судами. Обращается внимание на то, что, несмотря на исключение термина «подведомственность» из процессуального законодательства, нормы, разграничивающие компетенцию между различными юрисдикционными органами, были сохранены и интегрированы в институт подсудности, в результате чего произошло расширение института подсудности, изменились его сущность и назначение. Обновленный институт подсудности теперь выполняет две различные функции, имеющие одну цель, - определение судебной компетенции.

Результатом исследования стали выводы и предложения автора по доработке обновленного института подсудности на теоретическом уровне. В частности, предложена новая классификация института подсудности, позволяющая устранить сложности в понимании и применении новых правил подсудности.

Ключевые слова: гражданский прочесс, судебная власть, судебная компетениия, подведомственность, подсудность, виды подсудности.

Многие современные ученые [1], исследовавшие в своих работах вопросы судоустройственного и судопроизводственного характера, обращают внимание на высокую активность законодателя, направленную на модификацию органов судебной власти и, в частности, гражданского судопроизводства. Некоторым изменениям подверглись и правила, разграничивающие судебную компетенцию.

Судебная компетенция представляет собой правовой институт, включающий совокупность правовых норм, которые упорядочивают и структурируют компетенцию судов РФ по рассмотрению и разрешению возникающих правовых конфликтов. До внесения последних изменений содержание судебной компетенции составляли два самостоятельных института - подведомственность и подсудность. Они служили механизмом распределения дел между судами различных систем (подведомственность), а также между различными звеньями внутри одной судебной системы (подсудность).

Однако с 01.10.2019 Федеральным законом от 28.11.2018 № 451-Ф3 [2] применительно к разграничению полномочий судов общей юрисдикции и арбитражных судов термин «подведомственность» в Арбитражном процессуальном кодексе заменен термином «компетенция», а в Гражданском процессуальном кодексе - термином «подсудность» (гл. 3 ГПК РФ, гл. 4 АПК РФ). 
Несмотря на исключение из процессуальных кодексов термина «подведомственность», данный институт не был лишен своего содержания, поскольку нормативно закрепленные критерии в ст. 22, 22.1 ГПК РФ и ст. 27 АПК РФ (субъектный состав спора и определенный характер спорного правоотношения) позволяют разграничить дела между судами общей юрисдикции и арбитражными судами. Законодатель произвел интеграцию функций института подведомственности в институт подсудности, в результате чего произошло усложнение и расширение последнего.

Теперь институт подсудности гражданских дел приобрёл новые черты и направлен на определение компетенции судов общей юрисдикции по осуществлению правосудия по гражданским делам.

Данные поправки, фактически изменившие сущность института подсудности, были справедливо раскритикованы многими учеными. Так, по мнению Е.С. Смагиной, такая терминологическая замена «снижает уровень разграничения полномочий между судами общей юрисдикции и арбитражными судами, поскольку подведомственность сводится к подсудности». Она отмечает, что «старую» подведомственность втискивают в рамки отработанных правил подсудности, не создавая новые, таким образом меняя не просто терминологию, но содержание» [3]. Бекяшева Д.И. отмечает, что «отказ от термина «подведомственность» создаст путаницу в применении категории «подсудность» (в значении института «подведомственность») в соотношении с существующими в законодательстве видами подсудности - родовой и территориальной» [4]. В доктрине встречаются и прямо противоположные суждения: «Обсуждаемые новеллы - это не борьба за терминологическую чистоту; их глубинный смысл - ликвидация одной из предпосылок права на обращение в суд (подведомственности) и соответственно расширение перечня условий его реализации (подсудности)» [5].

В доктринальных источниках [6], посвященных институту подсудности, совершенно справедливо правила подсудности рассматриваются как важная конституционная гарантия для вынесения законного, обоснованного и справедливого решения.

Для реализации указанной конституционной гарантии необходимо совершенствование механизма распределения судебной компетенции по рассмотрению гражданских дел, в том числе посредством доктринальных разработок. Для облегчения процесса применения новых правил подсудности в гражданском процессе необходима новая классификация видов подсудности, охватывающая новые функции этого института. В этой связи предлагаем традиционную классификацию подсудности заменить на новую, в рамках которой подсудность будет делиться на два вида: внешнюю и внутреннюю. При этом внешняя подсудность будет направлена на разграничение компетенции между государственными и негосударственными судебными органами, а внутренняя подсудность - на разграничение компетенции внутри системы судов общей юрисдикции. Учитывая то, что в рамках внутренней подсудности разграничение компетенции будет осуществляться между различными звеньями системы судов общей юрисдикции, а также между одноуровневыми судами, представляется необходимым подразделить внутреннюю подсудность на родовую и территориальную по прежнему сценарию. В результате сущность института подсудности будет раскрываться через внешнюю в внутреннюю подсудность.

Внешнюю подсудность следует относить к статьям 22, 22.1 ГПК РФ и понимать под ней «институт гражданского процессуального права, включающий в себя совокупность правовых норм, направленных на разграничение компетенции между государственными (судом общей юрисдикции, арбитражным судом) и негосударственными судебными органами (третейским судом)». 
Анализ норм гражданского и арбитражного процессуального законодательства позволяет определить, что правила внешней подсудности распределяют компетенцию между судами общей юрисдикции и арбитражными судами методом исключения: судам общей юрисдикции подсудны все дела, за исключением тех, которые законом отнесены к компетенции арбитражных судов.

Содержание внутренней подсудности регламентируется ст. 23-32 ГПК РФ и представляет собой «правовой институт, регулирующий распределение гражданских дел, отнесенных к подсудности суда общей юрисдикции, между конкретными судами внутри системы».

Помимо терминологических и теоретико-научных последствий изменения, внесенные Федеральным законом № 451-Ф3, порождают еще одно новое правило, в соответствии с которым при выявлении нарушения правил подсудности после принятия иска к производству суды должны будут не оставлять иск без рассмотрения, а самостоятельно передавать дело в суд по правилам подсудности, в том числе из судов общей юрисдикции в арбитражный суд, и наоборот [7]. Если же отсутствие компетенции данной подсистемы судов выявлено на стадии принятия заявления, оно возвращается лицу в связи с неподсудностью [8]. Пришедшее на смену прекращению производства по делу правило о передаче дела по подсудности между судами общей юрисдикции и арбитражными судами (п. 2.1 ст. 33 ГПК РФ, ст. 39 АПК РФ в ред. Федерального закона № 451) приведет не только к восприятию судебной системы как единого юрисдикционного механизма, но и прежде всего позволит обеспечить доступность правосудия для лиц, нуждающихся в защите своих прав. Более того, «данное нововведение открывает возможности обсуждения новых оснований для передачи дел по подсудности, поскольку существующие на настоящий момент условия заточены на передачу дел по территориальной подсудности» [9].

На основе проведенного анализа изменений, внесенных в институт подсудности, можно сделать следующие выводы и предложения:

1. Изменения, внесенные в институт подсудности Федерального закона № 451-Ф3 по ряду своих положений, требуют доработки и конкретизации как в теоретическом, так и в конкретно-практическом плане.

2. В связи с отказом законодателя от термина «подведомственность» в гражданском процессе произошло расширение института подсудности, изменились его сущность и назначение. Обновленный институт подсудности выполняет две различные функции: «с одной стороны, разграничивает компетенцию между государственными и негосударственными судебными органами по защите нарушенных прав и охраняемых законом интересов; с другой - распределяет компетенцию внутри системы судов общей юрисдикции» [10].

3. В связи с тем, что новый институт подсудности выполняет две неоднородные функции, предлагаем подразделить исследуемый институт на два вида: внешнюю подсудность (разграничивающую компетенцию между государственными и негосударственными судебными органами) и внутреннюю подсудность (разграничивающую компетенцию внутри системы судов общей юрисдикции). Такая классификация обновленного института подсудности позволит более чётко определить сферу его использования и избежать различных толкований и сложностей в его применении. 


\section{Литература}

1. Кальницкий В.В., Николюк В.В. Изменения судоустройственного и судопроизводственного законодательства и позиции Верховного Суда РФ // Мировой судья. 2020. - № 3. - С. 3-8.

2. О внесении изменений в отдельные законодательные акты Российской Федерации: Федеральный закон от 28.11.2018 № 451-ФЗ (ред. от 17.10.2019) // СПС «КонсультантПлюс».

3. Смагина E.C. Завершена ли «процессуальная революция»? // Вестник гражданского процесса. - 2019. - № 4. - С. 113-123.

4. Бекяшева Д.И. Отказ законодателя от термина «подведомственность», или Уязвимые правила «новой» подсудности: что дальше? // Вестник гражданского процесса. 2019. - № 3. - С. 126-143.

5. Любченко M. Соблюдение норм о подведомственности как правовой пуризм: далеко идущие последствия. https://zakon.ru/blog/2019/2/25/soblyudenie_norm_o_podvedomstvennosti_kak_pravovoj_pu rizm_daleko_iduschie_posledstviya

6. Ерохина T. Соблюдение правил подсудности по делам, возникающим из публичных правоотношений, как гарантия права на судебную защиту // Арбитражный и гражданский процесс. - 2006. - № 9. - С. 13-17.

7. Валеев Д.Х., Загидуллин М.Р., Ситдиков Р.Б. Постатейный комментарий к Арбитражному процессуальному кодексу Российской Федерации // Вестник гражданского процесса. - 2019. - № 3. - С. 101-125.

8. Соловьев В.Ю. Процессуальная революция Верховного Суда Российской Федерации // Мировой судья. - 2018. - № 1. - С. 20-24.

9. Бараданченкова Н.Е. Новеллы института подведомственности // Арбитражный и гражданский процесс. - 2017. - № 12. - С. 24-25.

10. Гаджиалиева Н.Ш. Судебная компетенция по защите права на благоприятную окружающую среду // Юридический вестник ДГУ. - 2020. - № 2. - С. 121-127.

Поступила в редакиию 3 декабря 2020 г.

UDC-347.9

DOI: $10.21779 / 2500-1930-2020-35-4-104-108$

\section{Expansion of the Rules of Jurisdiction in Civil Proceedings}

\section{N.Sh. Gadzhialieva}

Dagestan State University; Russia, 367000, Makhachkala, M. Gadzhiev st., 43a; naidka79@mail.ru

The article is devoted to the analysis of the consequences of the elimination of the term 'jurisdiction' from procedural legislation as a result of the adoption of the Federal Law of November 28, 2018 № 451-FZ. Particularly, both the new content of the legal institution of jurisdiction and the updated rules for transferring a case according to jurisdiction between courts of general jurisdiction and arbitration courts are analyzed. Special attention is drawn to the fact that in connection with the refusal 
of the legislator from the term jurisdiction in civil proceedings, the institution of jurisdiction has expanded, its essence and purpose have changed. The renewed institution of jurisdiction now performs two different functions with one goal - the definition of judicial competence.

The study resulted in the author's conclusions and suggestions for improvement of the updated institution of jurisdiction at the theoretical level. Moreover, the author proposes a new classification of the institution of jurisdiction, which eliminates the difficulties in understanding and applying the new rules of jurisdiction.

Keywords: civil procedure, judicial power, judicial competence, jurisdiction, jurisdiction, types of jurisdiction.

Received 3 December, 2020 